\title{
Synthesis of Adherent Hydrophilic Polypyrrole Coatings onto
}

(Semi-)conducting Surfaces

Sabine Gabriel, ${ }^{\dagger}$ Michaël Cécius, ${ }^{\dagger}$ Karl Fleury-Frenette, ${ }^{\dagger}$ Robert Jérôme,${ }^{\dagger}$ Christine

$$
\text { Jérôme* }{ }^{* \dagger}
$$

${ }^{\dagger}$ Center for Education and Research on Macromolecules (C.E.R.M.), University of Liege, B6 Sart-Tilman, B-4000 Liège (Belgium).

${ }^{\ddagger}$ Centre Spatial de Liège, Université de Liège, B-4031 Angleur (Belgium).

\section{Supporting Information}

\section{Characterization of electrografted poly(Py-PEO-A)}

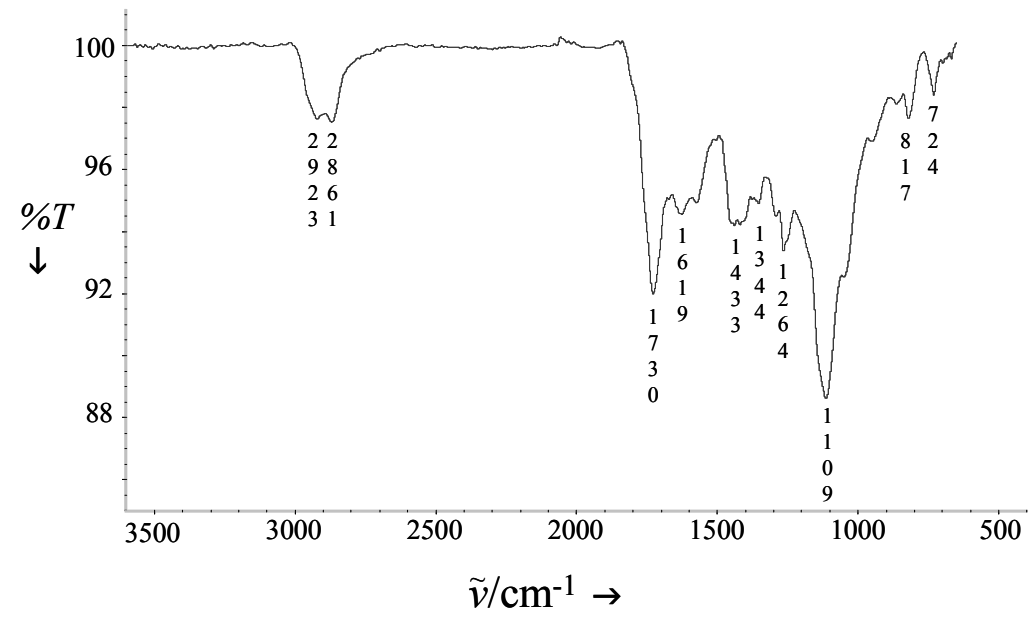

Figure S1: ATR-FTIR spectra for poly(Py-PEO-A) (0.5M) chemisorbed onto stainless steel.

[*] To whom correspondence should be addressed: tel. (32) 436634 91; fax (32) 436637 94; e-mail c.jerome@ulg.ac.be. 


\section{Functionalization of poly(Py/Py-PEO-OH) by Ferrocene-COOH}

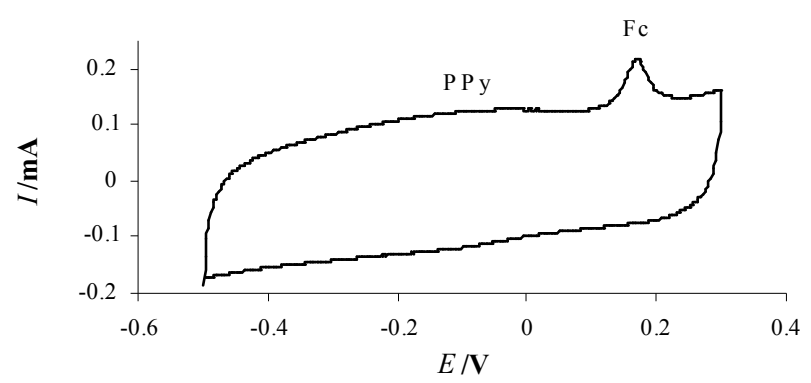

Figure S2: Cyclic Voltammograms recorded on C/poly(Py-PEO-A)/poly(Py/PyPEO-Fc) (50-50) in aqueous solution of $\mathrm{LiClO}_{4}(0.2 \mathrm{M})$ at $20 \mathrm{mV} / \mathrm{s}$ for a PPy film prepared with a total charge of $50 \mathrm{mC} / \mathrm{cm}^{2}$.

\section{Protein adsorption test}

The colorimetric test was based on the hydrolysis of nitrocefin by $\beta$-lactamase (see scheme below). The product (hydrolyzed nitrocefin) displays an absorption peak at 482 $\mathrm{nm}$.

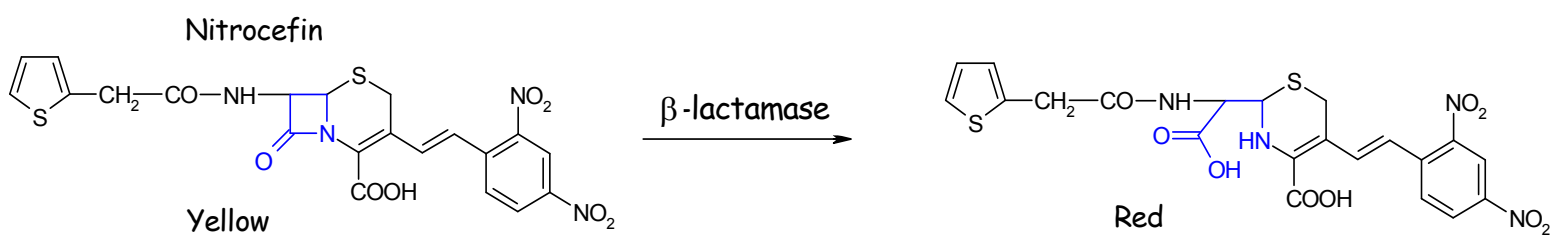

The activity of protein adsorbed onto the PPy film was measured by UV-VIS. A calibration curve was set up with standard $100 \mu \mathrm{M}$ nitrocefin solutions containing accurately known amounts of $\beta$-lactamase (from 0 to $100 \mathrm{ng}$ ). The conversion of the nitrocefin by the catalytic action of $\beta$-lactamase adsorbed on the polypyrrole films was monitored through changes of absorbance at $\lambda=482 \mathrm{~nm}$ as a function of time at room temperature. The rate of absorbance change vs. protein concentration plot was linear and fitted the equation: $\Delta \mathrm{A} / \mathrm{min}=0.0061 \times \mathrm{C}_{\text {protein }}$ (the time of the measurement is chosen in order to be in the linear region of the enzymatic reaction). 


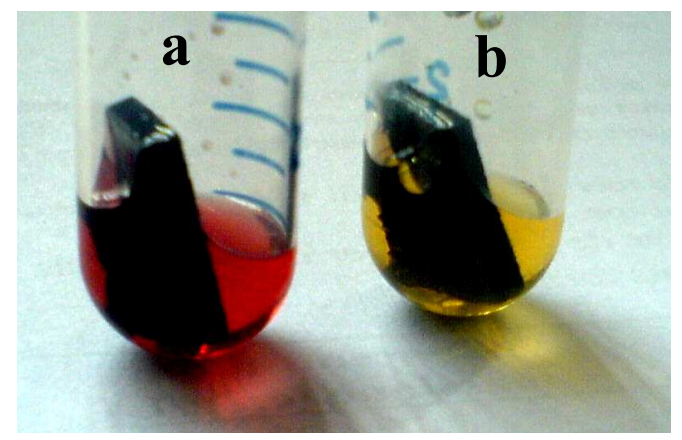

Figure S3: Observation of the nitrocefin solution $30 \mathrm{~min}$ after the immersion of glassy carbon halfcovered with (a) pure PPy (b) poly(Py/PyPEO) (50/50), and previously incubated in a $\beta$-lactamase solution. 